\title{
An evaluation of intergenic rRNA gene sequence length polymorphism analysis for the identification of Legionella species
}

\author{
N. K. FRY and T. G. HARRISON
}

Respiratory and Systemic Infection Laboratory, PHLS Central Public Health Laboratory, 61 Colindale Avenue, London NW9 5 HT

\begin{abstract}
There are currently more than $\mathbf{4 0}$ species of Legionella and the identification of most of these by standard methods is technically difficult. The aim of this study was to assess the suitability of a previously published PCR-based method of identifying Legionella spp. Intergenic 16S-23S rDNA spacer regions were amplified with primers complementary to conserved regions of the rRNA genes. Following electrophoretic separation of the products, data analyses were performed with the Taxotron ${ }^{(B)}$ software package. Computer-assisted analysis (with an empirically derived error tolerance of $3 \%$ ) could differentiate only 26 of the 43 strains (representing 43 species), with the remaining 17 species clustering into four groups (group I, comprising 10 species; group II, three species; group III, two species and group IV, two species). Analysis of well-characterised 'non-type' strains of some Legionella spp. (e.g., from type culture collections) resulted in patterns distinct from the corresponding type strain in most cases. Furthermore, recent isolates (identified by conventional methods) were identified by this PCR method to the presumed correct species (or species group) in only a minority of cases. Well characterised strains and recent isolates of Legionella showed heterogeneity within many species. This intra-species variation severely limits the usefulness of the method for the identification of isolates. However, this property may be useful for epidemiological typing within such species.
\end{abstract}

\section{Introduction}

The family Legionellaceae was initially proposed for a single genus, Legionella, and one species, L. pneumophila [1]. Currently, there are 42 validly described species [2-4] and several others awaiting formal description. To date, 18 of these species have been shown to be pathogenic for man [5]. The identification of the most common causative agent of legionellosis (L. pneumophila) by standard microbiological methods is straightforward $[6,7]$, but the lack of discriminatory phenotypic tests for Legionella spp. other than $L$. pneumophila makes their current identification difficult, costly and time-consuming. Several molecular methods of differentiation and identification of bacteria to the level of genus, species and strain have been applied to Legionella [8-13], including a method for the differentiation of Legionella spp. based on PCRamplification of the intergenic spacer region (ISR) of

Received 13 Sept. 1997; revised version accepted 3 Dec. 1997.

Corresponding author: Dr N. K. Fry. the $16 \mathrm{~S}$ and $23 \mathrm{~S}$ rRNA genes [14]. However, this latter study was based on patterns obtained with type strains of Legionella and only two recent isolates were examined. The aim of the present study was to fully evaluate this ISR method of identifying legionellae by compiling a database of patterns from the type strain of each species, and then to compare sets comprising (1) well-characterised strains (e.g., those available from type culture collections or those with 16S rRNA gene sequence or DNA:DNA homology data available) and (2) recent isolates (identified by standard methods) against this database. The Taxotron ${ }^{(\mathbb{B})}$ software package was used to assist in the analysis of the patterns.

\section{Materials and methods}

\section{Bacterial strains and culture conditions}

Type strains and other representatives of the 42 published species of Legionella and one proposed new species, 'L. donaldsonii' (R. J. Fallon and personal unpublished observations), were obtained from the culture collection of the Respiratory and Systemic 
Infection Laboratory (RSIL), the National Collection of Type Cultures (NCTC), Central Public Health Laboratory (CPHL), London and the American Type Culture Collection (ATCC), MD, USA. These are listed in Table 1 [2, 15-18]. Recent isolates, including clinical and environmental strains, were obtained from the RSIL, CPHL. Strains of legionellae were cultured on buffered charcoal yeast extract agar [19] at $30^{\circ}$ or $37^{\circ} \mathrm{C}$ in a moist chamber or, in the case of legionella-like amoebal pathogens (LLAPs), their amoebal host $[16,17,20]$.

Non-type strains of legionellae used in this study were divided into two sets: dataset I (52 strains) comprising well characterised strains and dataset II (46 strains) comprising recent clinical and environmental isolates. Strains assigned to dataset I were available either from type culture collections (NCTC or ATCC), or had been the subject of phylogenetic studies, such as $16 \mathrm{~S}$ rRNA (gene) sequence analysis $[16,17,20,21]$, DNA restriction fragment length polymorphism (RFLP) analysis [11], or DNA:DNA homology [18]; the identity of these strains was taken to be 'true'. Strains assigned to dataset II were identified in the RSIL by standard phenotypic techniques, including growth requirements, biochemical characteristics and serological tests with hyperimmune rabbit antisera $[6,7]$, or genotypic RFLP analysis [11]. Strains identified as $L$. pneumophila were confirmed by fluorescence microscopy with a $L$. pneumophila species-specific monoclonal antibody (Genetic Systems Corporation, Redmond, WA, USA). Consequently, confidence in the accuracy of the identity of these recent isolates ranged from 'strong' for L. pneumophila to 'poor' for the individual species within the blue-white autofluorescent group.

\section{Extraction of genomic DNA}

Genomic DNA suitable as template in the PCRs was extracted with the Nucleon ${ }^{(\hat{R}}$ genomic DNA extraction kit (GeneSys Biotech Ltd., Coatbridge, Strathclyde).

Table 1. Members of the family Legionellaceae showing the type strains of species used to establish the identification database designated 'type strain database'

\begin{tabular}{|c|c|c|c|c|c|}
\hline & Legionella species & NCTC no. & ATCC no. & Original designation & Clinical isolate \\
\hline 1. & L. pneumophila ${ }^{\mathrm{T} *}$ & 11192 & 33152 & Philadelphia-1 & Yes \\
\hline 2. & L. adelaidensis ${ }^{\mathrm{T}}$ & 12735 & 49625 & 1762-AUS-E & No \\
\hline 3. & L. anisa ${ }^{\mathrm{T}}$ & 11974 & 35292 & WA-316-C3 & Yes \\
\hline 4. & L. birminghamensis ${ }^{\mathrm{T}}$ & 12437 & 43702 & 1407-AL-H & No \\
\hline 5. & L. bozemanii ${ }^{\mathrm{T}}$ & 11368 & 33217 & WIGA & Yes \\
\hline 6. & L. brunensis ${ }^{\mathrm{T}}$ & 12240 & 43878 & $441-1$ & No \\
\hline 7. & L. cherrii $^{\mathrm{T}}$ & 11976 & 35252 & ORW & No \\
\hline 8. & L. cincinnatiensis ${ }^{\mathrm{T}}$ & 12438 & 43753 & $72-\mathrm{OH}-\mathrm{H}$ & Yes \\
\hline 9. & 'L. donaldsonii' & ND & ND & $86 / 35784$ & No \\
\hline 10. & L. dumoffii ${ }^{\mathrm{T}}$ & 11370 & 33279 & NY-23 & Yes \\
\hline 11. & L. erythra ${ }^{\mathrm{T}}$ & 11977 & 35303 & SE-32A-C8 & No \\
\hline 12. & L. fairfieldensis ${ }^{\mathrm{T}}$ & 12488 & 49588 & 1725-AUS-E & No \\
\hline 13. & L. feeleii ${ }^{\mathrm{T}}$ & 12022 & 35072 & WO-44C & Yes \\
\hline 14. & L. geestiana ${ }^{\mathrm{T}}$ & 12373 & 49504 & $51 / 83-1308$ & No \\
\hline 15. & L. genomospecies $1^{\mathrm{T}}$ & 13018 & 51913 & 2055-AUS-E & No \\
\hline 16. & L. gormanii ${ }^{\mathrm{T}}$ & 11401 & 33297 & LS-13 & Yes \\
\hline 17. & L. gratiana ${ }^{\mathrm{T}}$ & 12388 & 49413 & Lyon 8420412 & No \\
\hline 18. & L. hackeliae ${ }^{\mathrm{T}}$ & 11979 & 35250 & Lansing-2 & Yes \\
\hline 19. & L. israelensis ${ }^{\mathrm{T}}$ & 12010 & 43119 & Bercovier-4 & No \\
\hline 20. & L. jamestowniensis ${ }^{\mathrm{T}}$ & 11981 & 35298 & JA-26-GI-E2 & No \\
\hline 21. & L. jordanis ${ }^{\mathrm{T}}$ & 11533 & 33623 & BL-540 & Yes \\
\hline 22. & L. lansingensis ${ }^{\mathrm{T}}$ & 12830 & 49751 & 1677-MI-H & Yes \\
\hline 23. & L. londiniensis ${ }^{\mathrm{T}}$ & 12931 & 49505 & $59 / 84-1477$ & No \\
\hline 24. & L. longbeachae ${ }^{\mathrm{T}}$ & 11477 & 33462 & Long Beach-4 & Yes \\
\hline 25. & L. lytica & ND & ND & $\mathrm{L} 2$ & Yes \\
\hline 26. & L. maceachernii ${ }^{\mathrm{T}}$ & 11982 & 35300 & PX-1-G2-E2 & Yes \\
\hline 27. & L. micdadei ${ }^{\mathrm{T}}$ & 11371 & 33218 & TATLOCK & Yes \\
\hline 28. & L. moravica ${ }^{\mathrm{T}}$ & 12239 & 43877 & $316-36$ & No \\
\hline 29. & L. nautarum $^{\mathrm{T}}$ & 12932 & 49506 & $199 / 52-1224$ & No \\
\hline 30. & L. oakridgensis ${ }^{\mathrm{T}}$ & 11531 & 33761 & Oak Ridge-10 & No \\
\hline 31. & L. parisiensis ${ }^{\mathrm{T}}$ & 11983 & 35299 & $\mathrm{PF}-209 \mathrm{C}-\mathrm{C} 2$ & Yes \\
\hline 32. & L. quateirensis ${ }^{\mathrm{T}}$ & 12376 & 49507 & $200 / 83-1335$ & No \\
\hline 33. & L. quinlivanii ${ }^{\mathrm{T}}$ & 12433 & 43830 & 1442-AUS-E & No \\
\hline 34. & L. rubrilucens ${ }^{\mathrm{T}}$ & 11987 & 35304 & WA-270A-C2 & No \\
\hline 35. & L. sainthelensi ${ }^{\mathrm{T}}$ & 11988 & 35248 & Mt St. Helens-4 & Yes \\
\hline 36. & L. santicrucis ${ }^{\mathrm{T}}$ & 11989 & 35301 & SC-63-C7 & No \\
\hline 37. & L. shakespearei ${ }^{\mathrm{T}}$ & 12829 & 49655 & 214 & No \\
\hline 38. & L. spiritensis ${ }^{\mathrm{T}}$ & 11990 & 35349 & Mt St. Helens-9 & No \\
\hline 39. & L. steigerwaltii ${ }^{\mathrm{T}}$ & 11991 & 35302 & $\mathrm{SC}-18-\mathrm{C} 9$ & No \\
\hline 40. & L. tucsonensis ${ }^{\mathrm{T}}$ & 12439 & 49180 & 1087-AZ-H & Yes \\
\hline 41. & L. wadsworthii ${ }^{\mathrm{T}}$ & 11532 & 33877 & $81-716 \mathrm{~A}$ & Yes \\
\hline 42. & L. waltersii ${ }^{\mathrm{T}}$ & 13017 & 51914 & 2074-AUS-E & No \\
\hline 43. & L. worsleiensis $^{\mathrm{T}}$ & 12377 & 49508 & $95 / 83-1347$ & No \\
\hline
\end{tabular}

NCTC, National Collection of Type Cultures; ATCC, American Type Culture Collection; ND, not yet deposited; ${ }^{\mathrm{T}}$ type strain of species.

${ }^{*}$ L. pneumophila comprises three subspecies: subsp. pneumophila, fraseri and pascullei [2]. 
Template DNA from the LLAPs was kindly provided by R. Birtles, prepared by the Chelex (BioRad) extraction method [22], or by boiling a suspension of the organisms.

\section{PCR amplification of $16 S$ rDNA-23S rDNA intergenic spacer region}

This was performed essentially according to the method of Hookey et al. [14]. Genomic DNA was amplified by the PCR with primers complementary to regions on the 16S rRNA (Escherichia coli numbering [23], 1113-1130 [24]) and 23S rRNA (115-130 [25]) genes. The sequences of the primers were as follows: 5' CGC AAC GAG CGC AAC CCT 3' (primer 16S-f1130) and 5' GGG TTB CCC CAT TCG G 3' $(B=C / G / T$, primer 23S-r-115). Two alternative primers described by Riffard et al. [26] complementary to regions 1522-1542 (E. coli numbering) on the $16 \mathrm{~S}$ rRNA gene (5'-TGC GGC TGG ATC CCC TCC TT; primer FGPS 1490-72) and 115-132 on the 23S rRNA gene (5'-CCG GGT TTC CCC ATT CGG; primer FGPL $132^{\prime}-38$ ) were also used to amplify genomic DNA in some reactions. The PCR mixture contained $50 \mathrm{mM} \mathrm{KCl}, 10 \mathrm{~mm}$ Tris- $\mathrm{HCl}$ (pH 8.3), $3.5 \mathrm{~mm} \mathrm{MgCl}_{2}$, $200 \mu \mathrm{M}$ of each deoxynucleoside triphosphate (dATP, dCTP, dGTP and dTTP; Boehringer Mannheim), 110 pmols of each primer (PE Applied BioSystems, Warrington) and 1.25 U Taq polymerase (Life Technologies). Template DNA (c. $100 \mathrm{ng}$ ) was added and the mixture was overlaid with mineral oil (Sigma). Reaction mixtures with no added DNA served as negative controls. Alternatively, reaction mixtures without template and $T a q$ polymerase were prepared and overlaid with wax (Biowax; Biozym BV, Landgraaf; The Netherlands) and stored at $-30^{\circ} \mathrm{C}$ until use. Amplification was performed in a Trio-Thermoblock (Biometra) in 50- $\mu 1$ volumes under the following conditions: pre-denaturation for $5 \mathrm{~min}$ at $95^{\circ} \mathrm{C}$, then 27 cycles consisting of denaturation for $40 \mathrm{~s}$ at $95^{\circ} \mathrm{C}$, annealing for $42 \mathrm{~s}$ at $55^{\circ} \mathrm{C}$, extension for $1 \mathrm{~min}$ at $72^{\circ} \mathrm{C}$, followed by a final extension for $10 \mathrm{~min}$ at $72^{\circ} \mathrm{C}$. The effect of varying the amount of DNA template $(1,10$, 50 and $100 \mathrm{ng}$ ) in the PCR on the banding pattern was also examined.

\section{Analysis of PCR products}

PCR products (c. $10 \%$ of the reaction mixture) were separated by electrophoresis in poly(NAT) ${ }^{\mathrm{TM}}$ gels (Elchrom Scientific, Cham, Switzerland) $6 \% \mathrm{w} / \mathrm{v}$ in $30 \mathrm{~mm}$ Tris-acetate, $0.75 \mathrm{~mm}$ EDTA buffer, $\mathrm{pH} 8.2$, for $17 \mathrm{~h}$ at $25 \mathrm{~V}$. Electrophoresis was performed horizontally in a SEA $2000^{\mathrm{TM}}$ tank (Elchrom Scientific) connected to an external circulating waterbath at $20^{\circ} \mathrm{C}$. Molecular size markers (100-bp ladder, Life Technologies) were included in the outer two lanes of each eight-lane mini-gel (Elchrom Scientific). Following electrophoresis, gels were stained with ethidium bromide $(0.5 \mu \mathrm{g} / \mathrm{ml})$, destained in distilled water and photographed with Polaroid film Type 667 (Sigma).

\section{S1 nuclease treatment of PCR products}

The published method [14] treated the amplification products with $\mathrm{S} 1$ nuclease before separation by electrophoresis. To evaluate the use of this treatment, PCR-amplification products from strains of $L$. pneumophila were incubated with S1 nuclease (Boehringer Mannheim) with the recommended conditions $[14,27]$ for increasing times (1-15 $\mathrm{min})$ and then compared to untreated samples.

\section{Computer-assisted analysis of patterns}

Black and white photographs of the PCR gels were scanned with a ScanMaker (Microtek Lab) into Adobe Photoshop with 256 levels of grey and 150 dpi. The resultant tagged image file format (TIFF) files were then interpreted with four of the programs within the Taxotron ${ }^{\circledR}$ package (Taxolab ${ }^{\mathbb{R}}$; Institut Pasteur, Paris, France). These were RestrictoScan ${ }^{\mathbb{B}}$ (with no smoothing) for band detection and migration measurements; RestrictoTyper ${ }^{\mathbb{R}}$ for interpolation of fragment sizes from migration values (with the Schaffer and Sederoff algorithm [28]); Adanson ${ }^{\mathbb{B}}$ for clustering by singlelinkage and Dendrograph ${ }^{(\mathbb{R})}$ for constructing dendrograms. To ensure the highest quality of the results, the following steps were taken: (1) each molecular size 'standard lane' fitting curve was examined closely to verify that all data points were on or very close to the curve; (2) the schematic representation of bands drawn by RestrictoTyper ${ }^{\mathbb{B}}$ was visually compared to the actual bands on the photograph to detect any missing or artifactual bands. The problem of weak or unresolved bands is universal to the electrophoretic analysis of nucleic acid fragments or their resulting blots. The Taxotron ${ }^{\mathbb{R}}$ program allows the designation of bands as weak or doubtful, represented as thin lines by RestrictoTyper ${ }^{\mathbb{R}}$. Where confirmed visually, weak bands were included in the numerical analyses.

\section{Identification of patterns}

A database file was constructed containing the molecular sizes of bands resulting from the PCR with DNA from type strains of the 43 species (Table 1). Separate files containing the molecular sizes of bands resulting from 52 well-characterised strains (dataset I, see above) and 46 recent isolates (dataset II, see above) were prepared and then matched against this 'type strain database'. Preliminary analyses were done with various tolerance values (ranging from $1.0 \%$ to $10.0 \%$ ) to determine an optimal value that would give maximum discrimination between type strains and the highest number of correct identifications for strains in dataset I. The optimum error tolerance was determined to be $3.0 \%$ (see below) and this value was used for the rest of the study. 


\section{Results}

\section{Reproducibility of methodology}

The gel electrophoresis conditions used were shown to be highly reproducible. An example of a molecular size standard lane fitting curve with the 100-bp ladder is shown in Fig. 1. All the reference points were on, or very close to, the standard curve. Variation within the poly $(\mathrm{NAT})^{\mathrm{TM}}$ gels was determined by calculating the molecular sizes of bands from replicate samples (i.e., same PCR mixture) on the same gel. Mean molecular size estimates (from five replicates) of the three bands from ISR amplification of template DNA, e.g., $L$. pneumophila (NCTC strain 11191), were calculated to be 1453 (SD 4) bp, 878 (SD 5) bp and 845 (SD 2) bp. This corresponded to an SD of $<0.6 \%$ within gels. Variation between the poly(NAT) ${ }^{\mathrm{TM}}$ gels was determined by calculating the molecular sizes of bands from replicate samples (i.e., same PCR mixture) on five different gels. Mean molecular size estimates of the three bands described above were calculated to be 1433 (SD 13) bp, 878 (SD 7) bp and 848 (SD 6) bp, which corresponded to an SD of $<1.0 \%$ between gels. Mean molecular size estimates of three bands resulting from ISR amplification of the recent isolate LC4048 on three separate occasions, with template DNA from the same extraction, were calculated to be 1258 (SD 6) bp, 1063 (SD 5) bp and 456 (SD 5) bp. This corresponded to an $\mathrm{SD}$ of $<1.2 \%$ for different amplifications. Varying the amount of DNA template from 1 to $100 \mathrm{ng}$ (i.e., 1, 10, $50,100 \mathrm{ng}$ ) in the PCR had no significant effect on three of the four bands from the type strain of $L$. pneumophila; which yielded bands of 1412 (SD 2) bp, 863 (SD 1) bp and 828 (SD 3) bp, i.e., an SD of $<0.6 \%$. However, with $1 \mathrm{ng}$ of DNA template, the lowest molecular size band, calculated as 395 (SD 2) bp from the three results above, was very faint, such that it was not recognised as a band by RestrictoScan ${ }^{R}$.

\section{Intergenic spacer region patterns from type strains of Legionella}

The ISR method yielded relatively simple patterns, and analysis of the type strains of the 43 Legionella spp. confirmed that most could be differentiated visually (Fig. 2). To determine the optimum parameters for computer-assisted analysis, a file (type strain database) comprising molecular sizes of all the bands from the 43 type strains was compiled, against which well characterised non-type strains (dataset I) could be compared with a variety of fixed error tolerances. With a $1 \%$ tolerance, 39 of the 43 type strains could be identified, but only three of the 52 dataset I strains were identified to the correct species. Conversely, increasing the tolerance to $5 \%$ allowed the identification of 17 of the 52 dataset I strains to the correct species or species group, but discriminated between only 15 type strains (plus two groups of $\geqslant 10$ type strains). Therefore, the

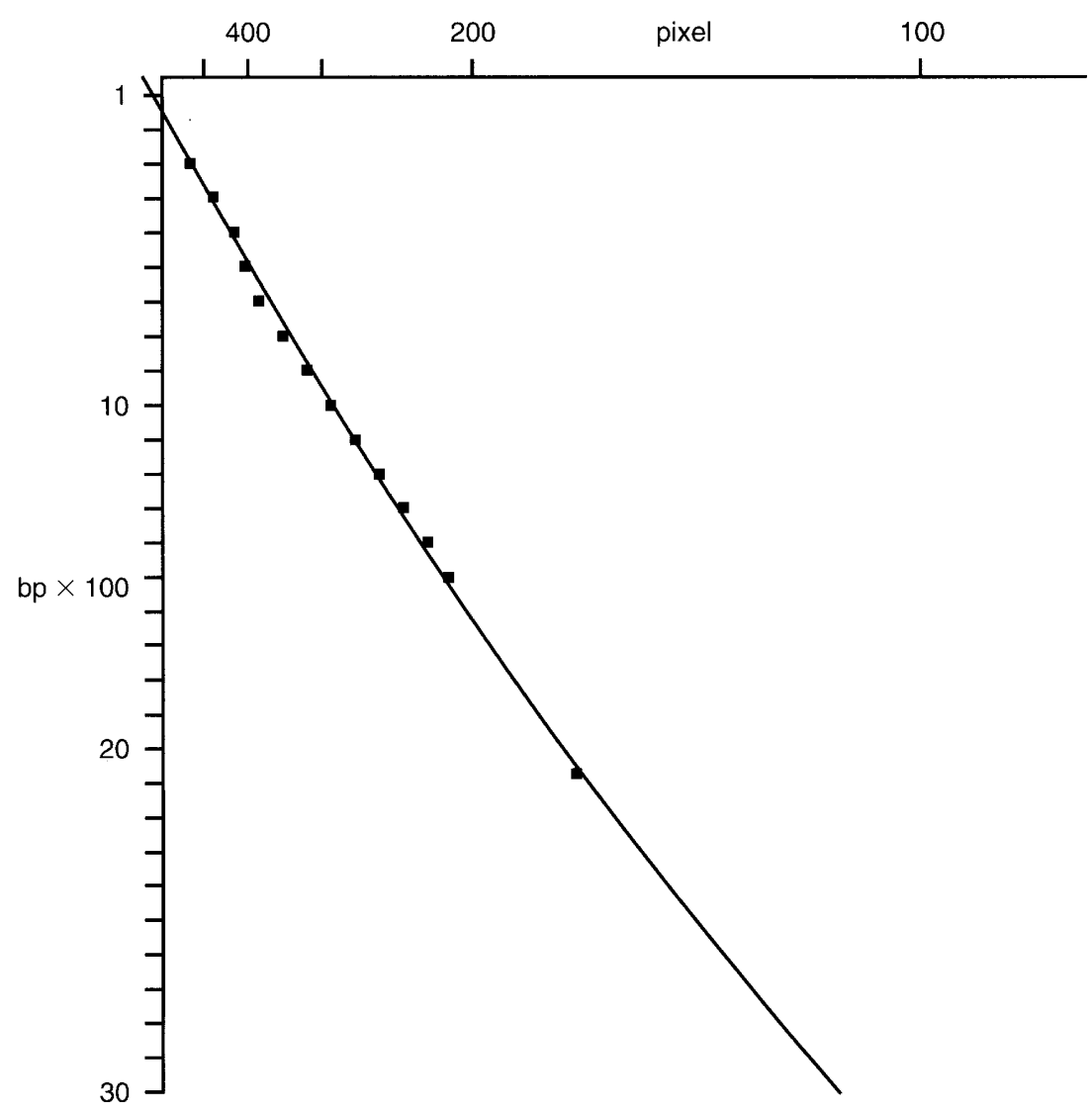

Fig. 1. Example of a standard lane fitting curve (100-bp ladder) drawn by Taxotron ${ }^{10}$ by the Schaffer and Sederoff method [28] showing the relationship between the inverse of migration distance (represented by pixel number) and fragment size. $\mathrm{SD}=27 \mathrm{bp}$. 


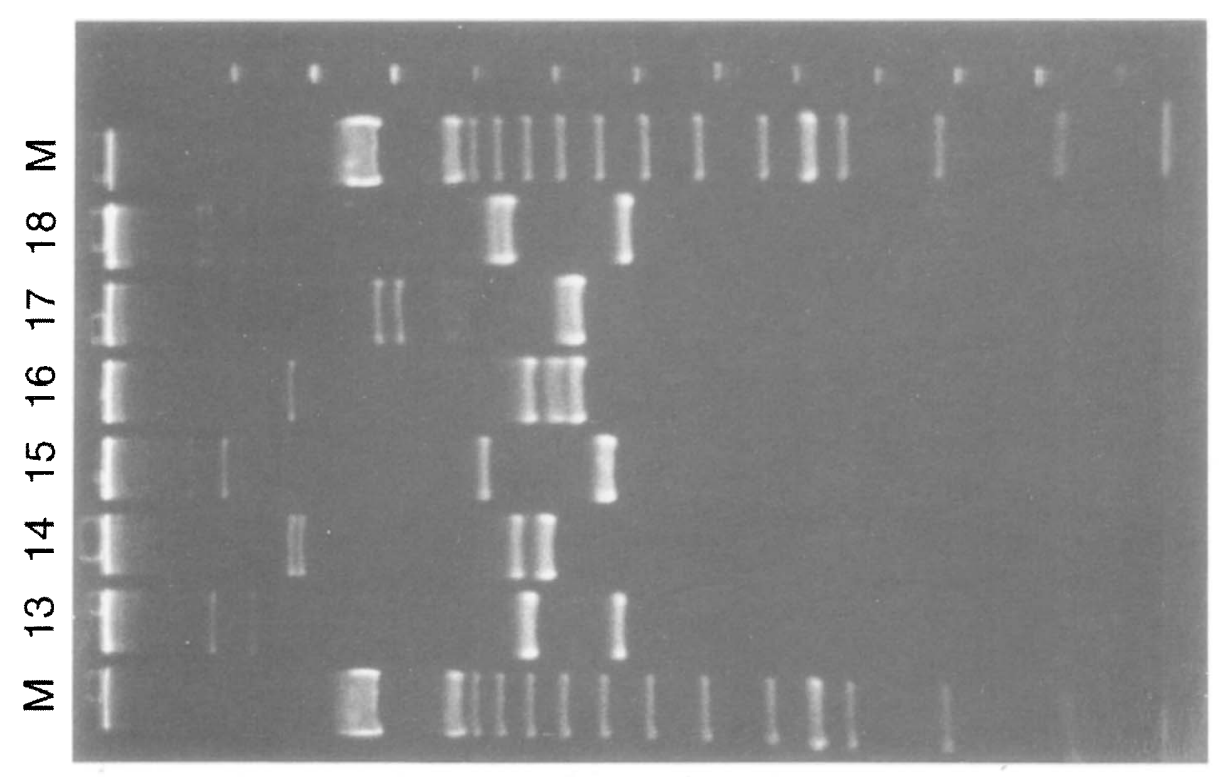

- $\therefore: 3$

$\because \frac{2}{2}$

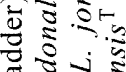

언드

\&ें

己高合

可

可证

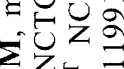

$\ddot{\otimes}: \stackrel{\Xi}{*}$

a

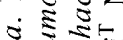

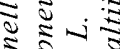

क人⿻

$\checkmark$ rio.

订宁的

동ㄴㄴ

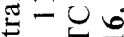

的证

브응

구의

武: ำ

过苋记

in

$m+n$

i $\infty=$

원

巳一⿻上丨

记

or $\operatorname{arm}$

$\Xi \cdots$

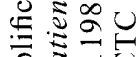

हे ڤ己

कi

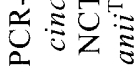

on $-i \div 3$

的部

อิ

$\frac{0}{2}$

$n=5$

$\geq \cup \dot{1}$

无宁

乙 $\infty$

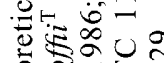

응

号设工

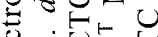

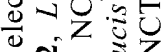

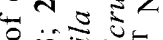

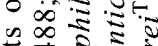
更

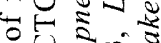
क 青的的

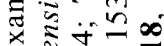
出过二

교요 호의 
value of $3 \%$ was selected as the optimum to give the greatest discrimination and likelihood of correct identification of the maximum number of species. With this value, 26 of the 43 type strains of Legionella could be differentiated (Fig. 3). The remaining 17
Legionella spp. clustered into four groups: group I (10 species), containing all the blue-white autofluorescent species, i.e., L. anisa, L. bozemanii, L. cherrii, $L$. dumoffi, $L$. genomospecies 1, L. gormanii, L. parisiensis, L. steigerwaltii, L. tucsonensis and one non-

Single linkage non-additive tree using a fixed tolerance of $3 \%$

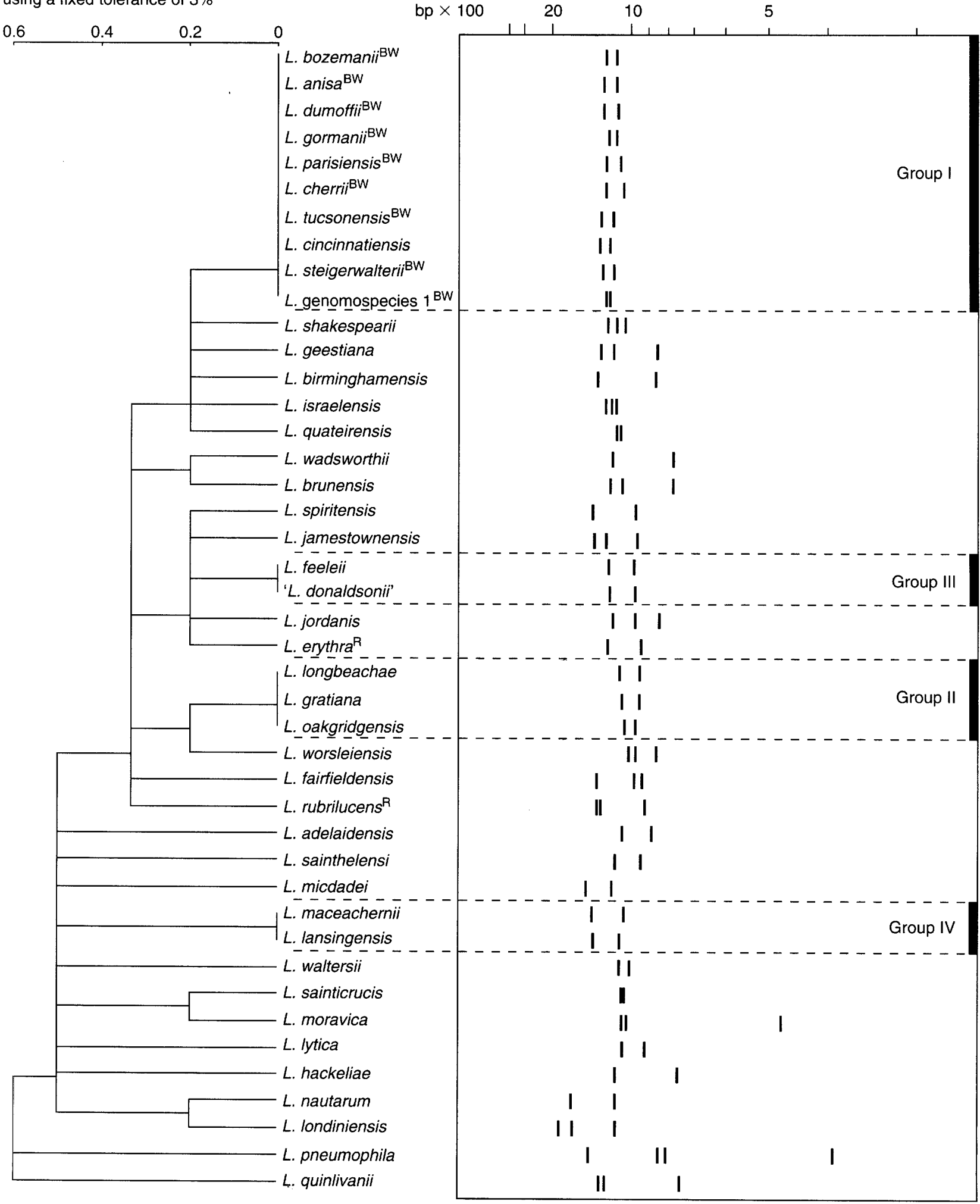

Fig. 3. Dendrogram and schematic representations (drawn by RestrictoTyper ${ }^{\mathbb{R}}$ ) of PCR-amplification of $16 \mathrm{~S}-23 \mathrm{~S}$ rDNA ISR from the type strains of 43 Legionella species. Patterns were clustered by the single linkage method with a fixed error tolerance of $3 \%$. Analyses were performed with the Taxotron ${ }^{\mathbb{B}}$ software package (Institut Pasteur). BW, bluewhite autofluorescent species; R, red autofluorescent species. 
autofluorescent species L. cincinnatiensis; group II (three species), L. gratiana, $L$. longbeachae and $L$. oakridgensis; group III (two species), L. lansingensis and L. maceachernii; and group IV (two species), $L$. feeleii and ' $L$. donaldsonii'. A dendrogram together with the schematic representation of bands drawn by RestrictoTyper $^{(\mathrm{R})}$ from the 43 type strains of Legionella with a fixed error tolerance of $3 \%$ is shown in Fig. 3.

Use of the primers described by Riffard et al. [26] also resulted in intra-species heterogeneity, i.e., ISR patterns distinct from the type strain, in Legionella spp. (data not shown).

\section{S1 nuclease treatment of PCR products}

PCR-amplification products from strains of L. pneumophila incubated with S1 nuclease for increasing times (1-15 min) were electrophoresed with the conditions described above. The resulting bands were smeared compared to the untreated samples, leading to less distinguishable bands and patterns (data not shown). Consequently, all the banding patterns presented here are from PCR products untreated with S1 nuclease.

\section{Data analysis of well-characterised strains of Legionella}

Molecular size files of ISR amplification products from well-characterised 'non-type' strains of $L$. pneumophila, L. bozemanii, L. dumoffii, L. erythra, L. feeleii, $L$. hackeliae, L. longbeachae, L. lytica, L. micdadei, L. quinlivanii, $L$. rubrilucens, $L$. sainthelensi and $L$. spiritensis were matched against the type strain database with an error tolerance of $1.0-10 \%$. Results from the comparison of these 'non-type' strains (dataset I) against the database of type strains with an error tolerance of $3 \%$ are shown in Table 2. Strains were identified to the correct species (or species group) in all cases for only seven of these 13 species. Strains from the other species were mis-identified in some or all cases.

\section{Data analysis of recent isolates of Legionella}

Recent isolates (identified by conventional methods) were identified to the presumed correct species (or species group) in only a minority of cases by the PCRbased method. Patterns from recent isolates of Legionella (dataset II) were matched against the 'type strain database' (see above). Results from the comparison of these strains against the database of type strains with a fixed error tolerance of $3 \%$ are shown in Table 3. Molecular size files of amplification products of the ISR from recent isolates were identified to the presumed correct species (or species group) for some strains belonging to the following 12 species: L. anisa, $L$. bozemanii, L. dumoffi, $L$. erythra, $L$. gormanii, $L$. jordanis, L. lytica, L. micdadei, L. nautarum, $L$. oakridgensis, $L$. spiritensis and $L$. steigerwaltii. Identification to the presumed correct species (or species group) was not achieved with any strains representing the following nine species: L. birminghamensis, L. cherrii, L. feeleii, L. maceachernii, $L$. rubrilucens, L. quinlivanii, L. pneumophila, L. sainthelensi and L. wadsworthii.

\section{ISR identification of L. pneumophila}

Of the 27 strains examined (including both well characterised and recent isolates) of $L$. pneumophila, 14 appeared to show similar patterns to the type strain (sharing the three major bands). However, with a fixed error tolerance of $3 \%$, only eight were recognised by ISR identification as L. pneumophila (Fig. 4).

\section{ISR identification of L. lytica and the Legionella- like amoebal pathogens}

Of the 11 strains of Legionella-like amoebal pathogens (LLAPs) tested, only two (LLAP-7 and LLAP-11) were identified as $L$. lytica. Patterns from all the remaining LLAPs were distinct from the type strain (data not shown).

\section{Discussion}

The principal aim of the study was to evaluate critically a published method for its suitability in the identification to species level of recent isolates of Legionella. Deviations from the previous method are fully acknowledged, i.e., method of DNA preparation, make of thermocycler, S1 nuclease digestion of PCR products, electrophoresis conditions and method of analysis. Such deviations were made only after preliminary investigation had shown that they led to improvements in reproducibility and data analysis.

Many of the ISR banding patterns from the type strains could be distinguished visually. However, a practical identification scheme for Legionella spp. should allow comparison of test strains against a previously characterised panel without the necessity of testing all previously characterised species at the same time. Thus some type of computer-assisted analysis is required. With the conditions determined to be optimal for this study (a fixed error tolerance of $3 \%$ ), the type strains could be differentiated for only $60 \%$ (26 of 43 ) of Legionella spp. This was not a result of variation resulting from the gel running conditions, as these were highly reproducible $(<1.5 \%)$, but rather because several species produced similar patterns with only small differences in the molecular size of some bands. These remaining species fell into four groups (comprising 10, three, two and two species, respectively). All the species in group I (except $L$. cincinnatiensis) demonstrated the phenotypic property of blue-white autofluorescence 
Table 2. Results of identification (with the Taxotron " package) of well-characterised strains of Legionella (dataset I) with a fixed error tolerance of $3 \%$

\begin{tabular}{|c|c|c|c|c|c|c|c|}
\hline \multirow[b]{2}{*}{$\begin{array}{l}\text { NCTC } \\
\text { no. }\end{array}$} & \multirow[b]{2}{*}{$\begin{array}{l}\text { Original } \\
\text { designation }\end{array}$} & \multirow[b]{2}{*}{$\begin{array}{l}\text { Legionella } \\
\text { species }\end{array}$} & \multirow[b]{2}{*}{ Serogroup } & \multicolumn{2}{|c|}{$\begin{array}{l}\text { Identification to Legionella } \\
\text { species or species group }\end{array}$} & \multirow[b]{2}{*}{$\begin{array}{l}\text { Closest match } \\
\text { within group }\end{array}$} & \multirow[b]{2}{*}{ Reference } \\
\hline & & & & Legionella spp. & $\begin{array}{l}\text { Variation } \\
\quad(\%)\end{array}$ & & \\
\hline 11191 & Pontiac-1 & L. pneumophila & 1 & L. pneumophila & 2.5 & $\ldots$ & \\
\hline 11230 & Togus-1 & L. pneumophila & 2 & No match & $\ldots$ & $\ldots$ & \\
\hline 11232 & Bloomington-2 & L. pneumophila & 3 & No match & $\ldots$ & $\ldots$ & \\
\hline 11233 & Los Angeles-1 & L. pneumophila & 4 & L. pneumophila & 3.0 & $\ldots$ & \\
\hline 11417 & Cambridge-2 & L. pneumophila & 5 & No match & $\ldots$ & $\ldots$ & \\
\hline 11287 & Oxford-1 & L. pneumophila & 6 & No match & $\ldots$ & $\cdots$ & \\
\hline 11406 & Chicago-2 & L. pneumophila & 6 & No match & $\ldots$ & $\ldots$ & \\
\hline 11984 & Chicago-8 & L. pneumophila & 7 & No match & $\ldots$ & $\ldots$ & \\
\hline 11985 & Concorde-3 & L. pneumophila & 8 & L. pneumophila & 3.0 & $\cdots$ & \\
\hline 11986 & IN-23-GI-C2 & L. pneumophila & 9 & No match & $\ldots$ & $\ldots$ & \\
\hline 12000 & Leiden-1 & L. pneumophila & 10 & L. pneumophila & 2.3 & $\ldots$ & \\
\hline 12179 & 797-PA-H & L. pneumophila & 11 & No match & $\ldots$ & $\ldots$ & \\
\hline 12180 & $570-\mathrm{CO}-\mathrm{H}$ & L. pneumophila & 12 & No match & $\ldots$ & $\cdots$ & \\
\hline 12181 & $82 \mathrm{~A} 3105$ & L. pneumophila & 13 & No match & $\ldots$ & $\ldots$ & \\
\hline \multirow[t]{3}{*}{12174} & 1169-MN-H & L. pneumophila & 14 & No match & $\ldots$ & $\ldots$ & \\
\hline & Lansing-3 & L. pneumophila & 15 & L. pneumophila & 3.0 & $\ldots$ & {$[2]$} \\
\hline & Jena-1 & L. pneumophila & 16 & L. pneumophila & 2.3 & $\cdots$ & {$[15]$} \\
\hline 11405 & Dallas-1E & $\begin{array}{l}\text { L. pneumophila subsp. } \\
\text { fraseri }\end{array}$ & $5 / 8 / 10$ & L. pneumophila & 2.5 & $\ldots$ & \\
\hline 12273 & U8W & $\begin{array}{l}\text { L. pneumophila subsp. } \\
\text { pascullei }\end{array}$ & & L. pneumophila & 1.5 & $\cdots$ & \\
\hline 11369 & MI-15 & L. bozemanii & 1 & No match & $\ldots$ & $\ldots$ & \\
\hline 11975 & Toronto-3 & L. bozemanii & 2 & Group I & 0.2 & L. dumoffii & \\
\hline \multirow[t]{3}{*}{11402} & TEX-KL & L. dumoffii & & Group I & 1.0 & L. dumoffii & \\
\hline & LC 1317 & L. erythra & & No match & $\ldots$ & $\ldots$ & {$[18]$} \\
\hline & LC709 & L. erythra & & L. erythra & 0.2 & $\ldots$ & [18] \\
\hline 11978 & 691-WI-H & L. feeleii & 2 & Group III & 1.5 & L. feeleii & \\
\hline 11980 & 798-PA-H & L. hackeliae & 2 & L. hackeliae & 1.3 & $\ldots$ & \\
\hline \multirow[t]{12}{*}{11530} & Tucker-1 & L. longbeachae & 2 & L. lytica & 2.0 & $\ldots$ & \\
\hline & LLAP-1 & L. lytica & & No match & $\ldots$ & $\ldots$ & {$[17]$} \\
\hline & LLAP-2 & L. lytica & & No match & $\ldots$ & $\cdots$ & {$[17]$} \\
\hline & LLAP-3 & L. lytica & & No match & $\ldots$ & $\ldots$ & {$[17]$} \\
\hline & LLAP-4 & L. lytica & & L. erythra & 2.0 & $\ldots$ & {$[17]$} \\
\hline & LLAP-6 & L. lytica & & No match & $\ldots$ & $\ldots$ & {$[16,17]$} \\
\hline & LLAP-7 & L. lytica & & L. lytica & 0.6 & $\ldots$ & {$[17]$} \\
\hline & LLAP-8 & L. lytica & & No match & $\ldots$ & $\ldots$ & [17] \\
\hline & LLAP-9 & L. lytica & & No match & $\ldots$ & $\ldots$ & {$[17]$} \\
\hline & LLAP-10 & L. lytica & & No match & $\ldots$ & $\ldots$ & {$[17]$} \\
\hline & LLAP-11 & L. lytica & & L. lytica & 1.6 & $\ldots$ & {$[17]$} \\
\hline & LLAP-12 & L. lytica & & No match & $\ldots$ & $\ldots$ & {$[17]$} \\
\hline 11372 & PPA & L. micdadei & & L. micdadei & 2.3 & $\ldots$ & \\
\hline 11403 & HEBA & L. micdadei & & L. micdadei & 0.4 & $\ldots$ & \\
\hline \multirow[t]{10}{*}{12434} & $\mathrm{LC} 870$ & L. quinlivanii & 2 & No match & $\ldots$ & $\ldots$ & \\
\hline & LC704 & L. rubrilucens & & No match & $\ldots$ & $\ldots$ & {$[18]$} \\
\hline & LC705 & L. rubrilucens & & No match & $\ldots$ & $\ldots$ & {$[18]$} \\
\hline & LC706 & L. rubrilucens & & No match & $\ldots$ & $\ldots$ & {$[18]$} \\
\hline & LC707 & L. rubrilucens & & No match & $\ldots$ & $\ldots$ & [18] \\
\hline & LC708 & L. rubrilucens & & No match & $\ldots$ & $\ldots$ & [18] \\
\hline & $\mathrm{LC} 805 \mathrm{H}$ & L. rubrilucens & & No match & $\cdots$ & $\cdots$ & [18] \\
\hline & LC805N & L. rubrilucens & & No match & $\ldots$ & $\ldots$ & [18] \\
\hline & LC985 & L. rubrilucens & & No match & $\ldots$ & $\ldots$ & {$[18]$} \\
\hline & LC1092 & L. rubrilucens & & No match & $\ldots$ & $\ldots$ & {$[18]$} \\
\hline 12450 & 1489-CA-H & L. sainthelensi & 2 & No match & $\ldots$ & $\ldots$ & \\
\hline 12082 & ML76 & L. spiritensis & 2 & L. spiritensis & 2.2 & $\ldots$ & \\
\hline
\end{tabular}

Identification was attempted by searching in the database for matching patterns, noting the percentage variation in size between the fragments in the tested pattern and that in the matching database pattern. The maximum percentage variation in fragment size is indicated. References for well characterised strains that are not available from the NCTC or ATCC are given.

(Fig. 3), and these species have been shown to be closely related phylogenetically by $16 \mathrm{~S}$ rDNA sequence analysis [21,29].

Differences in the ISR banding patterns of the type strains compared to those obtained by Hookey et al. [14] were apparent for most species. Although this could be caused by a number of factors, the most likely are the use of S1 nuclease and the electrophoresis conditions. The use of $\mathrm{S} 1$ nuclease was reported to digest unwanted single-stranded PCR products to give clearer banding patterns [14]. However, S1 nuclease can digest double-stranded DNA and cleave double-stranded nucleic acids at nicks or small gaps [27]. When applied in the present study, this treatment led to smearing of the banding patterns and could, 
Table 3. Results of identification test with the Taxotron ${ }^{k}$ package of a set of recent isolates identified by standard methods (dataset II)

\begin{tabular}{|c|c|c|c|c|c|}
\hline \multirow[b]{2}{*}{ APU no. } & \multirow{2}{*}{$\begin{array}{l}\text { Identification by } \\
\text { standard methods }\end{array}$} & \multirow[b]{2}{*}{ Serogroup } & \multicolumn{2}{|c|}{$\begin{array}{l}\text { Identification to Legionella species or } \\
\text { species group }\end{array}$} & \multirow{2}{*}{$\begin{array}{l}\text { Closest match } \\
\text { within group }\end{array}$} \\
\hline & & & Legionella $\mathrm{sp.}$ & Variation $(\%)$ & \\
\hline EUL22 & L. pneumophila & 1 & No match & $\ldots$ & $\ldots$ \\
\hline EUL26 & L. pneumophila & 1 & No match & $\ldots$ & $\ldots$ \\
\hline EUL56 & L. pneumophila & 1 & No match & $\ldots$ & $\ldots$ \\
\hline EUL61 & L. pneumophila & 1 & No match & $\ldots$ & $\ldots$ \\
\hline EUL66 & L. pneumophila & 1 & No match & $\ldots$ & $\ldots$ \\
\hline EUL75 & L. pneumophila & 1 & No match & $\ldots$ & $\ldots$ \\
\hline EUL96 & L. pneumophila & 1 & No match & $\ldots$ & $\ldots$ \\
\hline EUL31 & L. pneumophila & 1 & No match & $\ldots$ & $\ldots$ \\
\hline LC3962 & L. pneumophila & 3 & No match & $\ldots$ & $\ldots$ \\
\hline LC3934 & L. anisa & & Group I & 0.9 & L. anisa \\
\hline LC1276 & L. anisa/L. parisiensis & & Group I & 0.5 & L. tucsonensis \\
\hline LC2720 & L. birminghamensis & & No match & .. & $\ldots$ \\
\hline LC3266 & L. bozemanii & 1 & Group I & 1.1 & L. steigerwaltii \\
\hline LC3932 & L. bozemanii & 1 & No match & $\ldots$ & $\ldots$ \\
\hline LC777C & L. cherrii & & No match & $\ldots$ & $\ldots$ \\
\hline LC3664 & L. cherrii & & No match & $\ldots$ & $\ldots$ \\
\hline LC455 & L. dumoffii & & Group I & 1.3 & L. parisiensis \\
\hline LC3719 & L. erythra & & L. erythra & 2.2 & $\ldots$ \\
\hline LC797 & L. feeleii & 2 & No match & & $\ldots$ \\
\hline LC458 & L. gormanii & & L. gormanii & 2.3 & $\ldots$ \\
\hline LC1436 & L. jamestowniensis & & No match & & $\ldots$ \\
\hline LC3940 & L. jordanis & & L. jordanis & 1.6 & $\ldots$ \\
\hline LC818A & L. maceachernii & & No match & $\ldots$ & $\ldots$ \\
\hline LC3743 & L. maceachernii & & No match & & $\ldots$ \\
\hline LC858 & L. micdadei & & L. micdadei & 0.3 & $\ldots$ \\
\hline LC3745 & L. micdadei & & No match & $\ldots$ & $\ldots$ \\
\hline LCl128 & L. nautarum & & No match & & $\ldots$ \\
\hline LC3779 & L. nautarum & & L. nautarum & 1.0 & $\ldots$ \\
\hline LC3845 & L. nautarum & & No match & $\ldots$ & $\ldots$ \\
\hline $\mathrm{LC} 1251$ & L. oakridgensis & & No match & $\ldots$ & $\ldots$ \\
\hline LC3741 & L. oakridgensis & & No match & & $\ldots$ \\
\hline LC3780 & L. oakridgensis & & L. oakridgensis & 0.7 & $\ldots$ \\
\hline LC2763 & L. parisiensis & & No match & $\ldots$ & $\ldots$ \\
\hline LC3505 & L. quinlivanii & 2 & No match & $\ldots$ & $\ldots$ \\
\hline LC3764 & L. rubrilucens & & No match & $\ldots$ & $\ldots$ \\
\hline LC3851 & L. rubrilucens & & No match & $\ldots$ & $\ldots$ \\
\hline LC3936 & L. sainthelensi & 2 & No match & $\ldots$ & $\ldots$ \\
\hline LC4042 & L. spiritensis & 1 & No match & $\ldots$ & $\ldots$ \\
\hline LC738 & L. steigerwaltii & & No match & $\ldots$ & $\ldots$ \\
\hline LC777B & L. steigerwaltii & & Group I & 2.0 & L. anisa/L. steigerwaltit \\
\hline LC1329 & L. tucsonensis & & No match & $\ldots$ & $\ldots$ \\
\hline LC121 & L. wadsworthii & & No match & $\ldots$ & $\ldots$ \\
\hline LC4045* & Legionella sp. & & L. erythra & 2.8 & $\ldots$ \\
\hline $\mathrm{LC} 4046^{\dagger}$ & Legionella $\mathrm{sp}$. & & No match & $\ldots$ & $\ldots$ \\
\hline LC4048* & Legionella $\mathrm{sp}$. & & No match & $\ldots$ & $\ldots$ \\
\hline LC4049 & Legionella sp. & & No match & $\ldots$ & $\ldots$ \\
\hline
\end{tabular}

APU, Atypical Pneumonia Unit, Respiratory and Systemic Infection Laboratory, CPHL, London.

${ }^{*}$ Turin I no. 1, ${ }^{\dagger}$ Montbeliard A1, ${ }^{*}$ Greoux $11 \mathrm{D} 13$, and ${ }^{\S}$ Mulhouse B26; represent putative new species, subspecies or serogroups (J. Etienne, personal communication).

potentially, lead to the loss of lower molecular size bands and the digestion of higher molecular size bands to artificially lower sizes, thus it was not used for the main study. In the authors' laboratory, the use of poly(NAT) ${ }^{\mathrm{TM}}$ pre-cast gels and controlled electrophoresis conditions resulted in greatly increased resolution, sensitivity and reproducibility compared to electrophoresis by the conditions in the method published previously [14] (data not shown). These factors, combined with use of the Taxotron ${ }^{(\mathrm{B})}$ software package, enabled precise size estimation of the band sizes to be achieved. The error tolerance of $3 \%$ used in the study was chosen empirically. Extensive analyses were done with various values $(1.0-10.0 \%)$ to maximise the potential for an unknown pattern to be matched correctly. However, given the great similarity of many of these patterns, any additional 'true matches' achieved at higher tolerance levels were always accompanied by a greater number of mismatches.

Well-characterised non-type strains from 14 species were identified to the correct species (or species group) in some cases. However, strains from the eight other species for which strains were available were not identified, or identified incorrectly. In contrast to the previously published method [14], discrimination of the type strains of the two red autofluorescent species, L. erythra and L. rubrilucens, was achieved by the method described here. This difference is likely to be 


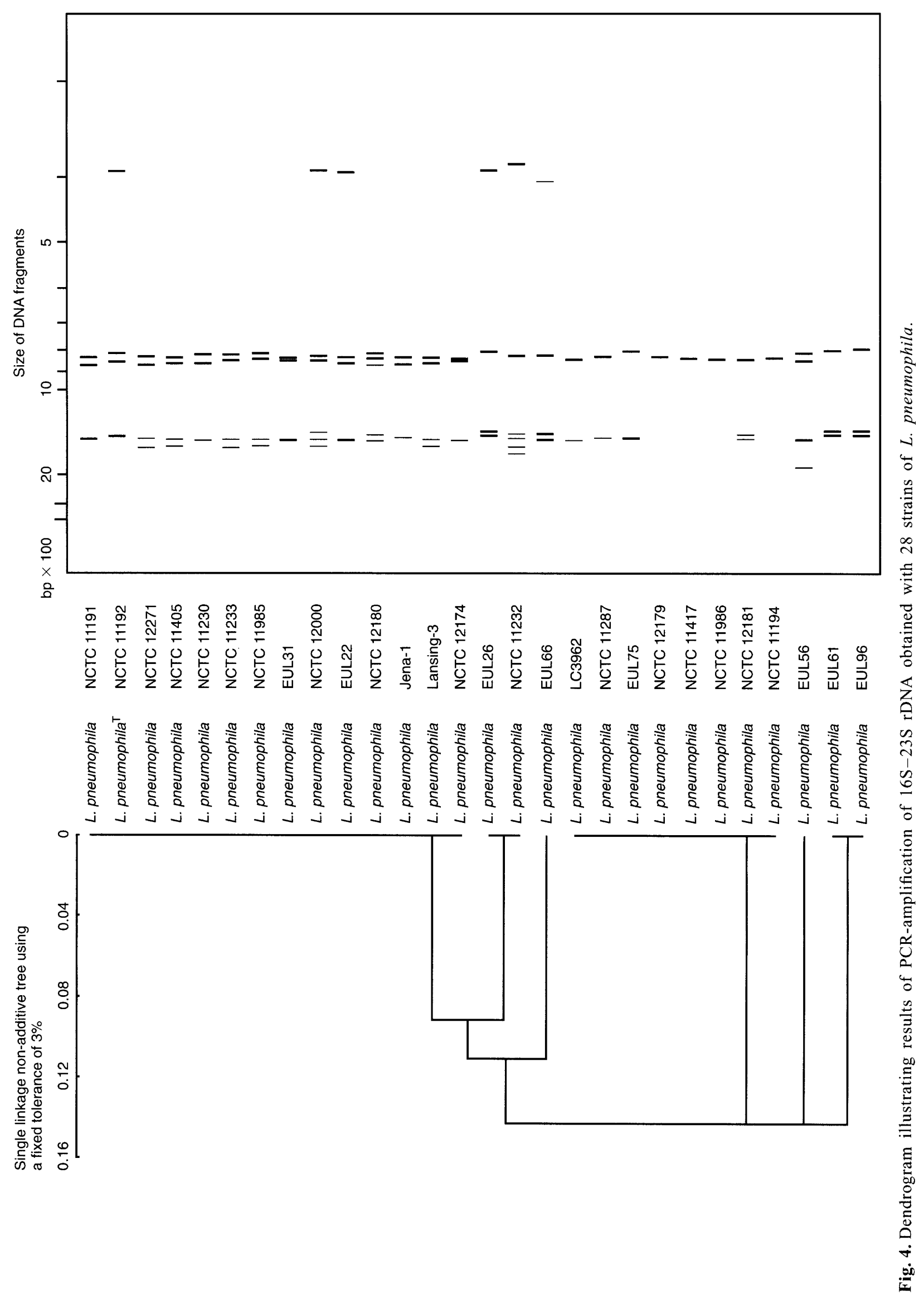


related to the increased resolution of the gels and running conditions used in this study. However, although two recent isolates of L. erythra (LC709 and LC1317 [18]) were examined and correctly identified, none of the nine strains of L. rubrilucens was identified correctly.

It has been proposed that LLAPs should not all be placed in the single species L. lytica, but should be split into at least five species $[17,20]$. Whilst some of the ISR patterns obtained in this study showed correlation with the proposed new species, the agreement was not absolute (personal unpublished observations). However, the analysis of the ISR here is not a phylogenetic one and the relationships revealed by such analyses must be treated with caution.

The small number of strains of $L$. pneumophila recognised correctly by ISR identification may demonstrate the heterogeneity of this species (Fig. 4). An alternative and more likely explanation is that as $L$. pneumophila was the only species with a large number of isolates available for testing, this result may indicate what would be found for many other species of Legionella if multiple recent isolates were available for analysis.

The choice of primers obviously affects the resulting band patterns in ISR analysis. There are several wellcharacterised regions that can be used as targets to amplify all copies of the $16 \mathrm{~S}-23 \mathrm{~S}$ rDNA spacer positions. In the $16 \mathrm{~S}$ rRNA gene, there are three highly conserved positions, i.e., 1390-1407, 15251541 and 1491-1506 (E. coli numbering [30,31]). From the available $23 \mathrm{~S}$ rRNA gene sequence data, six conserved regions within the first $520 \mathrm{bp}$ of the gene have been described [30]. Gürtler et al. [31] recommended optimum primer target regions for amplification of the $16 \mathrm{~S}-23 \mathrm{~S}$ rDNA spacer region. Neither of the primers chosen by Hookey et al. [14] targeted these regions and, furthermore, the forward primer has one mis-match with Legionella spp. $16 \mathrm{~S}$ rDNA in this region. However, it appears unlikely that this factor alone would explain the failure of the ISR method. The purpose of this study was to evaluate the published method [14] for its use in the identification of new isolates, hence the primers of Hookey et al. [14] were used. However, to take account of the recommendation above [31], an alternative primer pair [26] was examined, but also demonstrated intraspecies variation in the ISR patterns obtained.

The identification and typing of bacteria by PCRamplification of the ISR of the $16 \mathrm{~S}$ and $23 \mathrm{~S}$ rRNA genes has been described for several genera [31, 32]. Such banding patterns obtained with $16 \mathrm{~S}$ and $23 \mathrm{~S}$ rDNA primers described previously are assumed to be the result of specific amplification of these target regions. However, in the absence of supporting sequence data or adequate description of the rRNA operons, the presence of multiple, often weak bands, must be regarded with caution. It may be that some of the resulting bands are not genuine amplicons from the $16 \mathrm{~S}-23 \mathrm{~S}$ rDNA intergenic region. That such methods have been demonstrated to be successful for the identification of other genera to species level may reflect true homogeneity within those species or in some cases may reflect the paucity of strains examined.

The patterns resulting from the amplification of the 16S-23S rDNA ISR do appear to be distinct and stable for some species of Legionella. However, intraspecies heterogeneity and a high degree of interspecies similarity of patterns for many of the species makes identification by this method unsuitable for the genus as a whole. This study illustrates the importance of testing recent isolates (preferably in large numbers) when investigating any potential identification system. It is possible that the apparent intra-species variation observed in many of the species could be exploited for epidemiological typing for these particular species. However, for the family Legionellaceae, identification to the species level remains a challenge which may be better addressed by investigating alternative target sites in the genome.

We thank Dr T. Rowbotham, Leeds Public Health Laboratory, Dr R. Birtles, Unité des Rickettsies, Marseille and Professor J. Etienne, Faculté de Médecine R. Laennec, Lyon, France for providing some of the strains used in this study. We also thank Professor P.A.D. Grimont and Dr Francine Grimont, Institut Pasteur, Paris, France, for advice in the use of the Taxotron ${ }^{\text {ik }}$ software package, Carol Persaud for valuable technical support and Dr R.C. George for critical review of the manuscript. Finally, strain $86 / 35784$ was characterised and the name ' $L$. donaldsonii' sp. nov. was proposed for this new species by Dr R. J. Fallon, Ruchill Hospital, Glasgow. Dr Fallon sadly died before the final studies and formal description of this species were completed, and this paper is dedicated to his memory.

\section{References}

1. Brenner DJ, Steigerwalt AG, McDade JE. Classification of the Legionnaires' disease bacterium: Legionella pneumophila, genus novum, species nova, of the family Legionellaceae, familia nova. Ann Intern Med 1979; 90: 656-658.

2. Brenner DJ, Steigerwalt AG, Epple $\mathbf{P}$ et al. Legionella pneumophila serogroup Lansing 3 isolated from a patient with fatal pneumonia, and descriptions of L. pneumophila subsp. pneumophila subsp. nov., L. pneumophila subsp. fraseri subsp. nov., and L. pneumophila subsp. pascullei subsp. nov. J Clin Microbiol 1988; 26: 1695-1703.

3. Harrison TG, Saunders NA. Taxonomy and typing of legionellae. Rev Med Microbiol 1994; 5: 79-90.

4. Benson RF, Thacker WL, Daneshvar MI, Brenner DJ Legionella waltersii sp. nov, and an unnamed Legionella genomospecies isolated from water in Australia. Int $J$ Syst Bacteriol 1996; 46: 631-634.

5. Lo Presti F, Riffard S, Vandenesch F et al. The first clinical isolate of Legionella parisiensis, from a liver transplant patient with pneumonia. J Clin Microbiol 1997; 35: 1706-1709.

6. Harrison TG, Taylor AG. Phenotypic characteristics of legionellae. In: Harrison TG, Taylor AG (eds) A laboratory manual for Legionella. Chichester, John Wiley and Sons. 1988: 45-56.

7. Harrison TG, Taylor AG. Identification of legionellae by serological methods. In: Harrison TG, Taylor AG (eds) A laboratory manual for Legionella. Chichester, John Wiley and Sons. 1988: $57-68$ 
8. Saunders NA, Harrison TG, Haththotuwa A, Kachwalla N, Taylor AG. A method for typing strains of Legionella pneumophila serogroup 1 by analysis of restriction fragment length polymorphisms. $J$ Med Microbiol 1990; 31: 45-55.

9. Laussucq S, Schuster D, Alexander WJ, Thacker WL, Wilkinson HW, Spika JS. False-positive DNA probe test for Legionella species associated with a cluster of respiratory illnesses. $J$ Clin Microbiol 1988; 26: 1442-1444.

10. Grimont F, Lefèvre M, Ageron E, Grimont PAD. rRNA gene restriction patterns of Legionella species: a molecular identification system. Res Microbiol 1989; 140: 615-626.

11. Saunders NA, Harrison TG, Kachwalla N, Taylor AG. Identification of species of the genus Legionella using a cloned rRNA gene from Legionella pneumophila. $J$ Gen Microbiol 1988; 134: 2363-2374.

12. Robinson PN, Heidrich B, Tiecke F, Fehrenbach FJ, Rolfs A. Species-specific detection of Legionella using polymerase chain reaction and reverse dot-blotting. FEMS Microbiol Lett 1996; 140: $111-119$.

13. Pinar A, Ahkee S, Miller RD, Ramirez JA, Summersgill JT. Use of heteroduplex analysis to classify legionellae on the basis of 5S rRNA gene sequences. $J$ Clin Microbiol 1997; 35: 1609-1611.

14. Hookey JV, Birtles RJ, Saunders NA. Intergenic 16S rRNA gene (rDNA)-23S rDNA sequence length polymorphisms in members of the family Legionellaceae. J Clin Microbiol 1995; 33: $2377-2381$.

15. Lück PC, Helbig JH, Ehret W, Ott M. Isolation of a Legionella pneumophila strain serologically distinguishable from all known serogroups. Int J Microbiol Virol Parasitol Infect Dis 1995; 282: $35-39$

16. Fry NK, Rowbotham TJ, Saunders NA, Embley TM. Direct amplification and sequencing of the $16 \mathrm{~S}$ ribosomal DNA of an intracellular Legionella species recovered by amoebal enrichment from the sputum of a patient with pneumonia. FEMS Microbiol Lett 1991; 83: 165-168.

17. Birtles RJ, Rowbotham TJ, Raoult D, Harrison TG. Phylogenetic diversity of intra-amoebal legionellae as revealed by $16 \mathrm{~S}$ rRNA gene sequence comparison. Microbiology 1996; 142: $3525-3530$.

18. Saunders NA, Doshi N, Harrison TG. A second serogroup of Legionella erythra serologically indistinguishable from Legionella rubrilucens. J Appl Bacteriol 1992; 72: 262-265.

19. Edelstein PH. Improved semiselective medium for isolation of Legionella pneumophila from contaminated clinical and environmental specimens. J Clin Microbiol 1981; 14: 298-303.

20. Adeleke A, Pruckler J, Benson R, Rowbotham T, Halablab M,
Fields B. Legionella-like amoebal pathogens - phylogenetic status and possible role in respiratory disease. Emerg Infect Dis 1996; 2: 225-230.

21. Fry NK, Warwick S, Saunders NA, Embley TM. The use of $16 \mathrm{~S}$ ribosomal RNA analyses to investigate the phylogeny of the family Legionellaceae. J Gen Microbiol 1991; 137: $1215-1222$.

22. Ochert AS, Boulter AW, Birnbaum W, Johnson NW, Teo CG Inhibitory effect of salivary fluids on PCR: potency and removal. PCR Methods Appl 1994; 3: 365-368.

23. Brosius J, Palmer ML, Kennedy PJ, Noller HF. Complete nucleotide sequence of a $16 \mathrm{~S}$ ribosomal RNA gene from Escherichia coli. Proc Natl Acad Sci USA 1978; 75: $4801-4805$.

24. Hookey JV, Bryden J, Gatehouse L. The use of 16S rDNA sequence analysis to investigate the phylogeny of Leptospiraceae and related spirochaetes. $J$ Gen Microbiol 1993; 139: 2585-2590.

25. Lane DJ. 16S/23S rRNA sequencing. In: Stackebrandt E, Goodfellow $M$ (eds) Nucleic acid techniques in bacterial systematics. Chichester, John Wiley and Sons. 1991: 115-175.

26. Riffard S, Lo Presti F, Normand P et al. Use of an intergenic $16 \mathrm{~S}-23 \mathrm{~S}$ rRNA-gene PCR assay to differentiate Legionella species. EWGLI Book of Abstracts, 12th Meeting of the European Working Group on Legionella Infections, Lisbon, Portugal, 1-3 June 1997: 26.

27. Sambrook J, Fritsch EF, Maniatis T. Molecular cloning; A laboratory manual, 2nd edn. Cold Spring Harbor, NY, Cold Spring Harbor Laboratory Press. 1989.

28. Schaffer HE, Sederoff RR. Improved estimation of DNA fragment lengths from agarose gels. Anal Biochem 1981; 115: $113-122$.

29. Hookey JV, Saunders NA, Fry NK, Birtles RJ, Harrison TG. Phylogeny of Legionellaceae based on small-subunit ribosomal DNA sequences and proposal of Legionella lytica comb. nov. for Legionella-like amoebal pathogens. Int J Syst Bacteriol 1996; 46: 526-531.

30. Weisburg WG, Barns SM, Pelletier DA, Lane DJ. 16S ribosomal DNA amplification for phylogenetic study. $J$ Bacteriol 1991; 173: 697-703

31. Gürtler V, Stanisich VA. New approaches to typing and identification of bacteria using the $16 \mathrm{~S}-23 \mathrm{~S}$ rDNA spacer region. Microbiology 1996; 142: 3-16.

32. Jensen MA, Webster JA, Straus N. Rapid identification of bacteria on the basis of polymerase chain reaction-amplified ribosomal DNA spacer polymorphisms. Appl Environ Microbiol 1993; 59: $945-952$. 